\title{
Crystal Structure, Polymorphism, and Anisotropic Thermal Expansion of $\alpha-\mathrm{Ca}\left(\mathrm{CH}_{3} \mathrm{COO}\right)_{2}$
}

\author{
Published as part of a Crystal Growth and Design virtual special issue on The Rietveld Refinement Method: Half \\ of a Century Anniversary
}

Sebastian Bette,* Gerhard Eggert, Sebastian Emmerling, Martin Etter, Thomas Schleid, and Robert E. Dinnebier

Cite This: Cryst. Growth Des. 2020, 20, 5346-5355

Read Online

ACCESS | 니 Metrics \& More | 四 Article Recommendations | SI Supporting Information

ABSTRACT: Dehydration of calcium acetate monohydrate (Ca$\left.\left(\mathrm{CH}_{3} \mathrm{COO}\right)_{2} \cdot \mathrm{H}_{2} \mathrm{O}\right)$ by heating to $300{ }^{\circ} \mathrm{C}$ leads to the formation of anhydrous $\alpha-\mathrm{Ca}\left(\mathrm{CH}_{3} \mathrm{COO}\right)_{2}$. During heating and cooling cycles, high- and low-temperature forms of $\alpha-\mathrm{Ca}\left(\mathrm{CH}_{3} \mathrm{COO}\right)_{2}$ were discovered. The reversible first-order phase transformation between the two forms occurs in a temperature range between 150 and $170{ }^{\circ} \mathrm{C}$. The crystal structures were solved from laboratory powder X-ray diffraction (PXRD) data. The low temperature form of $\alpha$-calcium acetate (LT- $\alpha$ - $\left.\mathrm{Ca}\left(\mathrm{CH}_{3} \mathrm{COO}\right)_{2}\right)$ crystallizes at room temperature in a primitive triclinic unit cell with space group $P \overline{1}$ with lattice parameters of $a=8.7168(3) \AA, b=12.6408(3) \AA, c=$ 12.3084(3) $\AA, \alpha=117.4363(17)^{\circ}, \beta=77.827(2)^{\circ}, \gamma=$ $115.053(2)^{\circ}$, and a unit cell volume of $1090.23(6) \AA^{3}$. High-

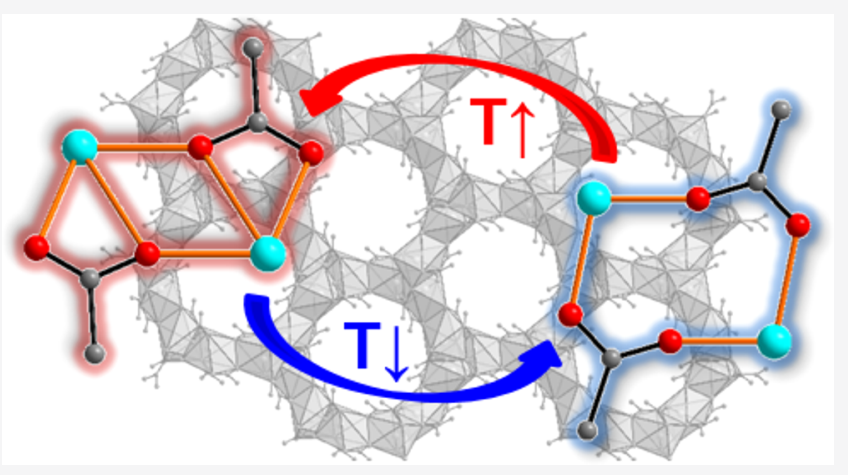
temperature $\alpha$-calcium acetate $\left(\mathrm{HT}-\alpha-\mathrm{Ca}\left(\mathrm{CH}_{3} \mathrm{COO}\right)_{2}\right)$ crystallizes at $300{ }^{\circ} \mathrm{C}$ in a rhombohedral unit cell with space group $R \overline{3}$, lattice parameters of $a=21.1030(5) \AA, c=8.7965(2) \AA$, and a unit cell volume of 3392.58(17) $\AA^{3}$. In both crystal structures, edge sharing polyhedra of calcium cations and acetate anions that coordinate in both a mono- and bidentate way build up channel-like motifs. During the phase transition, the coordination mode of a bridging acetate anion changes from monodentate to bidentate, and the elliptical channels of the low temperature form become circular. This leads to both negative and positive thermal expansion along different principal axes in the crystal structure of LT- $\alpha-\mathrm{Ca}\left(\mathrm{CH}_{3} \mathrm{COO}\right)_{2}$ and to an overall considerably big volumetric thermal expansion.

\section{INTRODUCTION}

Calcium acetate salts are seemingly simple compounds that are used for various purposes such as a binder for phosphorus for the treatment of hyperphosphatemia ${ }^{1}$ or as a food additive. ${ }^{2}$ In nature, pure calcium acetate hydrates do not occur as minerals, and only a mixed calcium copper acetate hydrate named paceite $\left(\mathrm{CaCu}\left(\mathrm{CH}_{3} \mathrm{COO}\right)_{4} \cdot 6 \mathrm{H}_{2} \mathrm{O}\right)$ has been found yet. ${ }^{3}$ Recently, it was demonstrated that calcium acetate monohydrate (Ca$\left.\left(\mathrm{CH}_{3} \mathrm{COO}\right)_{2} \cdot 1 \mathrm{H}_{2} \mathrm{O}\right)$ occurs as an intermediate during the mechanochemical synthesis of paceite or of a mixed cadmium calcium acetate hydrate $\left(\mathrm{CaCd}\left(\mathrm{CH}_{3} \mathrm{COO}\right)_{4} \cdot 6 \mathrm{H}_{2} \mathrm{O}\right) .{ }^{4}$ Calcium acetate hydrate salts, $\mathrm{Ca}\left(\mathrm{CH}_{3} \mathrm{COO}\right)_{2} \cdot n \mathrm{H}_{2} \mathrm{O}$ with $n=1 / 2$ and 1 , occur as efflorescence phases on calcareous heritage objects such as eggs, mollusca shells, ${ }^{5}$ or ancient pottery. ${ }^{6}$ The acetate salts form from the reaction of acetic acid, which is emitted by wood from wooden storage furniture and showcases, ${ }^{7}$ with calcium carbonate. This phenomenon is known as Byne's disease ${ }^{8}$ and has been observed since the end of the 19th century. Calcium carboxylate zigzag chains form the structural backbone of the efflorescence phases, ${ }^{9}$ which enables the incorporation of other ions such as formates ${ }^{10}$ or nitrates, ${ }^{11}$ into the coordination sphere of calcium or the intercalation of chloride anions ${ }^{12-14}$ or water molecules ${ }^{15,16}$ in between the chains.

The simple binary system $\mathrm{Ca}\left(\mathrm{CH}_{3} \mathrm{COO}\right)_{2} \cdot \cdot \mathrm{H}_{2} \mathrm{O}$ exhibits a surprisingly large variety of solid phases. In aqueous solution, $\mathrm{Ca}\left(\mathrm{CH}_{3} \mathrm{COO}\right)_{2} \cdot \mathrm{H}_{2} \mathrm{O}$ is the thermodynamically stable phase. ${ }^{6,17}$ There are three different polymorphs of this monohydrate, ${ }^{18-20}$ but only one crystallizes from a pure aqueous calcium acetate solution. ${ }^{18}$ Upon heating, $\mathrm{Ca}\left(\mathrm{CH}_{3} \mathrm{COO}\right)_{2} \cdot \mathrm{H}_{2} \mathrm{O}$ releases water in three discrete steps, leading to calcium acetate subhydrates, $\mathrm{Ca}\left(\mathrm{CH}_{3} \mathrm{COO}\right)_{2} \cdot n \mathrm{H}_{2} \mathrm{O}$, with water contents of $n=1 / 2$ and $n=$

Received: April 25, 2020

Revised: June 11, 2020

Published: June 12, 2020 
$1 / 4^{21}$ and finally to anhydrous calcium acetate, which also exhibits three different polymorphs, $\gamma-, \beta$-, and $\alpha$-Ca$\left(\mathrm{CH}_{3} \mathrm{COO}\right)_{2} \cdot{ }^{22} \mathrm{Up}$ to 2020 , only the crystal structures of the monohydrates have been determined. ${ }^{18-20}$ Recently, we were able to solve the crystal structure of $\mathrm{Ca}\left(\mathrm{CH}_{3} \mathrm{COO}\right)_{2} \cdot 1 / 2 \mathrm{H}_{2} \mathrm{O} .^{23}$ At ambient conditions, this hemihydrate crystallizes in a large unit cell of almost $12000 \AA^{3}$ and exhibits a collagen-like triple helix motif. During the thermal decomposition of this compound, we observed the formation of $\beta$ - and $\alpha$-Ca$\left(\mathrm{CH}_{3} \mathrm{COO}\right)_{2}$ as short living intermediates. While the powder $\mathrm{X}$-ray diffraction (PXRD) data for the $\beta$-form showed good agreement with the reference data, we obtained a completely different powder pattern of $\alpha-\mathrm{Ca}\left(\mathrm{CH}_{3} \mathrm{COO}\right)_{2}$ as compared to the reported ones by Walter-Levy ${ }^{22}$ or Panzer. ${ }^{21}$ This and the lack of structural knowledge of "simple" compounds such as anhydrous calcium acetate motivated us to perform a detailed investigation on $\alpha-\mathrm{Ca}\left(\mathrm{CH}_{3} \mathrm{COO}\right)_{2}$. In this paper, we present the crystal structures of the low (LT- $\left.\alpha-\mathrm{Ca}\left(\mathrm{CH}_{3} \mathrm{COO}\right)_{2}\right)$, which matches the previously published reference data for $\alpha$ $\mathrm{Ca}\left(\mathrm{CH}_{3} \mathrm{COO}\right)_{2}$ and the high-temperature form (HT- $\alpha$-Ca$\left.\left(\mathrm{CH}_{3} \mathrm{COO}\right)_{2}\right)$ of $\alpha$-calcium acetate and a detailed study on its anisotropic thermal expansion.

\section{EXPERIMENTAL SECTION}

Synthesis. $\mathrm{Ca}\left(\mathrm{CH}_{3} \mathrm{COO}\right)_{2} \cdot \mathrm{H}_{2} \mathrm{O}$ was used as a precursor material for $\alpha-\mathrm{Ca}\left(\mathrm{CH}_{3} \mathrm{COO}\right)_{2}$. For the production of well crystalline Ca$\left(\mathrm{CH}_{3} \mathrm{COO}\right)_{2} \cdot \mathrm{H}_{2} \mathrm{O}$, a saturated calcium acetate solution produced by dissolving $\mathrm{Ca}\left(\mathrm{CH}_{3} \mathrm{COO}\right)_{2} \cdot \mathrm{H}_{2} \mathrm{O}(\mathrm{VWR},>99 \%)$ in deionized water was filled in a terracotta pot that was placed in desiccators with a volume of 2 $\mathrm{L}$ at room temperature $\left(22-24{ }^{\circ} \mathrm{C}\right)$. In the desiccator, a relative humidity $(\mathrm{RH})$ of $75 \%$ was obtained by adding a vessel filled with saturated sodium chloride solution. The desiccators were stored for 6 weeks. During the storage, white efflorescence crystals formed on the outer surface of the pots. The purity of the recrystallized Ca$\left(\mathrm{CH}_{3} \mathrm{COO}\right)_{2} \cdot \mathrm{H}_{2} \mathrm{O}$ was proven by PXRD (Supporting Information, Figure $\mathrm{S} 1$ ).

For the production of $\alpha-\mathrm{Ca}\left(\mathrm{CH}_{3} \mathrm{COO}\right)_{2}, \mathrm{Ca}\left(\mathrm{CH}_{3} \mathrm{COO}\right)_{2} \cdot \mathrm{H}_{2} \mathrm{O}$ was heated in an argon stream of $50 \mathrm{~mL} / \mathrm{min}$ up to $350^{\circ} \mathrm{C}$ with a heating rate of $2 \mathrm{~K} / \mathrm{min}$. The temperature was kept constant for $1 \mathrm{~h}$. Afterward, the solid was cooled down in the argon stream to room temperature with a cooling rate of $2 \mathrm{~K} / \mathrm{min}$.

Phase Characterization. Scanning electron microscopy (SEM) of the calcium acetate hydrate phases was performed with a TESCAN Vega TS $5130 \mathrm{MM}$ (20 kV accelerating voltage) scanning electron microscope after the samples were coated with gold. Infrared spectra were recorded in attenuated total reflection (ATR) geometry on a "PerkinElmer Spectrum Two" device equipped with a diamond crystal. The background spectrum was measured separately and subtracted. Elemental analyses of carbon, hydrogen, sulfur, and nitrogen were performed with a Vario Micro Cube analyzer (Elementar). Thermal analysis was carried out using a STA 449 F5-Jupiter (Netzsch) device for TG measurements. Approximately $32 \mathrm{mg}$ of the sample was placed in an $\mathrm{Al}_{2} \mathrm{O}_{3}$ crucible and heated from 30 to $350^{\circ} \mathrm{C}$, subsequently cooled to $30{ }^{\circ} \mathrm{C}$, heated again to $350{ }^{\circ} \mathrm{C}$, and finally cooled to $30^{\circ} \mathrm{C}$ with a heating and cooling rate of $5 \mathrm{~K} / \mathrm{min}$ in a $50 \mathrm{~mL} / \mathrm{min}$ Ar-stream. An empty $\mathrm{Al}_{2} \mathrm{O}_{3}$ crucible was used as a reference. For background measurements $32 \mathrm{mg}$ of corundum $\left(\alpha-\mathrm{Al}_{2} \mathrm{O}_{3}\right)$ was subjected to the same temperature program. Prior to the measurement, the corundum was calcinated at $1000{ }^{\circ} \mathrm{C}$ for $2 \mathrm{~h}$. Sorption measurements were performed on a Quantachrome Instruments Autosorb iQ 3 with nitrogen $\left(\mathrm{N}_{2}\right)$ at $77 \mathrm{~K}$ or carbon dioxide $\left(\mathrm{CO}_{2}\right)$ at $273 \mathrm{~K}$ as adsorbate. The samples were activated under high vacuum at either room temperature or $120^{\circ} \mathrm{C}$ for $12 \mathrm{~h}$ before measurement. The BrunauerEmmett-Teller surface area $\left(S_{\mathrm{BET}}\right)$ was determined from the nitrogen isotherm from the linear regime in the pressure range $0.1<p / p_{0}<0.3$. Prior and after the sorption measurement, PXRD patterns were recorded (Figure S2) in order to ensure that the substance can withstand the high vacuum atmosphere during the activation process. PXRD patterns for phase identification were collected at room temperature on a laboratory powder diffractometer in Debye-Scherrer geometry (Stadi P-diffractometer (Stoe), $\mathrm{Cu}-\mathrm{K}_{\alpha 1}$ radiation from primary $\mathrm{Ge}(111)$-Johann-type monochromator, triple array of Mythen $1 \mathrm{~K}$ detectors (Dectris)). The samples were sealed in $0.5 \mathrm{~mm}$ diameter borosilicate glass capillaries (Hilgenberg glass no. 0140), which were spun during the measurements. Each pattern was measured in a $2 \theta$ range from $1.0^{\circ}$ to $110^{\circ}$ applying a total scan time of $1 \mathrm{~h}$. The PXRD pattern for the crystal structure solution of LT- $\alpha-\mathrm{Ca}\left(\mathrm{CH}_{3} \mathrm{COO}\right)_{2}$ was collected using the same device by only using one Mythen $1 \mathrm{~K}$ detector of the triple array and applying a scan range from $2.0^{\circ}$ to $110^{\circ} 2 \theta$ and a total scan time of $20 \mathrm{~h}$. Temperature-dependent in situ X-ray diffraction experiments were performed on a D8-Advance diffractometer (Bruker, $\mathrm{Cu}-\mathrm{K}_{\alpha 1}$ radiation from primary $\mathrm{Ge}(111)$-Johann-type monochromator, Lynx Eye position sensitive detector (Bruker)) in Debye-Scherrer geometry using a water-cooled furnace (mri capillary heater, (251000) ${ }^{\circ} \mathrm{C}$ ) for heating the capillary. The sample was loaded into a 0.5 $\mathrm{mm}$ diameter quartz glass capillary (Hilgenberg), which was also spun during the measurements. The patterns were measured with a scan range of $5.0^{\circ} 2 \theta$ to $40.0^{\circ} 2 \theta$, employing a step size of 0.005 and a total scan time of $4 \mathrm{~h}$. A delay time of $30 \mathrm{~min}$ was applied prior to each measurement to ensure thermal equilibration. The PXRD pattern for the crystal structure solution of HT- $\alpha-\mathrm{Ca}\left(\mathrm{CH}_{3} \mathrm{COO}\right)_{2}$ was collected using the same device. Thereto, the sample was heated to $300{ }^{\circ} \mathrm{C}$ and measured applying a scan range from $5.0^{\circ}$ to $90^{\circ} 2 \theta$ and a total scan time of $20 \mathrm{~h}$. Temperature-dependent in situ synchrotron PXRD measurements were performed in Debye-Scherrer geometry at a wavelength of $\lambda=0.20713 \AA(\sim 60 \mathrm{keV})$ on beamline P02.1 at the Deutsches Elektronen-Synchtrotron (DESY)/PETRA III synchrotron in Hamburg, Germany. The sample was loaded in an open $0.5 \mathrm{~mm}$ quartz capillary that was heated by an in-house built ceramic heater up to $350{ }^{\circ} \mathrm{C}$ with a heating rate of $2 \mathrm{~K} / \mathrm{min}$. The temperature was kept constant for $30 \mathrm{~min}$, and then the sample was cooled with a cooling rate of $2 \mathrm{~K} / \mathrm{min}$. Diffraction patterns were recorded in $5 \mathrm{~K}$ intervals. For this purpose, a delay of 5 min was applied prior to each measurement in order to allow thermal equilibration. For the measurements the sample was illuminated for $1 \mathrm{~min}$. The scattered X-rays were detected by a $2 \mathrm{D}$ detector (PerkinElmer XRD1621 CN3-EHS with a pixel size of $200 \times$ $200 \mu \mathrm{m}^{2}$ and a pixel area of $2048 \times 2048$ pixels) that was mounted orthogonal to the beam path with a sample-to-detector distance of 1378 $\mathrm{mm}$. The collected Debye-Scherrer rings were subsequently azimuthally integrated with the pyFAI-software ${ }^{24}$ to one-dimensional powder diffraction patterns in $Q\left[\mathrm{~nm}^{-1}\right]$ and $2 \theta\left[^{\circ}\right]$ versus intensity. Parameters for intensity integration were determined from a NIST silicon reference sample (NIST 640d). Further mask generation, polarization correction, and azimuthal integration of the $2 \mathrm{D}$ patterns were performed using the xpdtools software. ${ }^{25}$

Crystal Structure Solution. The program TOPAS $6.0^{26}$ was used to determine and refine the crystal structures of LT- and HT- $\alpha$ $\mathrm{Ca}\left(\mathrm{CH}_{3} \mathrm{COO}\right)_{2}$. Indexing of the powder patterns was carried out by iterative use of singular value decomposition (LSI) ${ }^{27}$ and led to a primitive triclinic cell for the low temperature phase with $P \overline{1}$ and $P 1$ as most probable space groups and to a rhombohedral cell for the high temperature phase with $R \overline{3}, R 3, R \overline{3} \mathrm{~m}$, and $R 3 \mathrm{~m}$ as most probable space groups. The lattice parameters are given in Figure 2. Le Bail ${ }^{28}$ fits applying the fundamental parameter approach of TOPAS ${ }^{29}$ were employed to determine the peak profile and the precise lattice parameters. For modeling of the background, Chebychev polynomials of sixth order were used. The refinements converged quickly.

The crystal structures were solved by applying the global optimization method of simulated annealing (SA) in real space as it is implemented in TOPAS. ${ }^{30}$ Considering the determined unit cell volume, the space group symmetry and the packing density of the related calcium acetate monohydrate ${ }^{18-20}$ the molar content of the unit cells was expected to be around $Z=6$ for LT- $\alpha-\mathrm{Ca}\left(\mathrm{CH}_{3} \mathrm{COO}\right)_{2}$ and around $Z=18$ for $\mathrm{HT}-\alpha-\mathrm{Ca}\left(\mathrm{CH}_{3} \mathrm{COO}\right)_{2}$. Accordingly and with respect to the space symmetry, for the low temperature phase three calcium and six acetate ions and for the high temperature phase one calcium and two acetate ions were put into the unit cell and freely translated and rotated. 


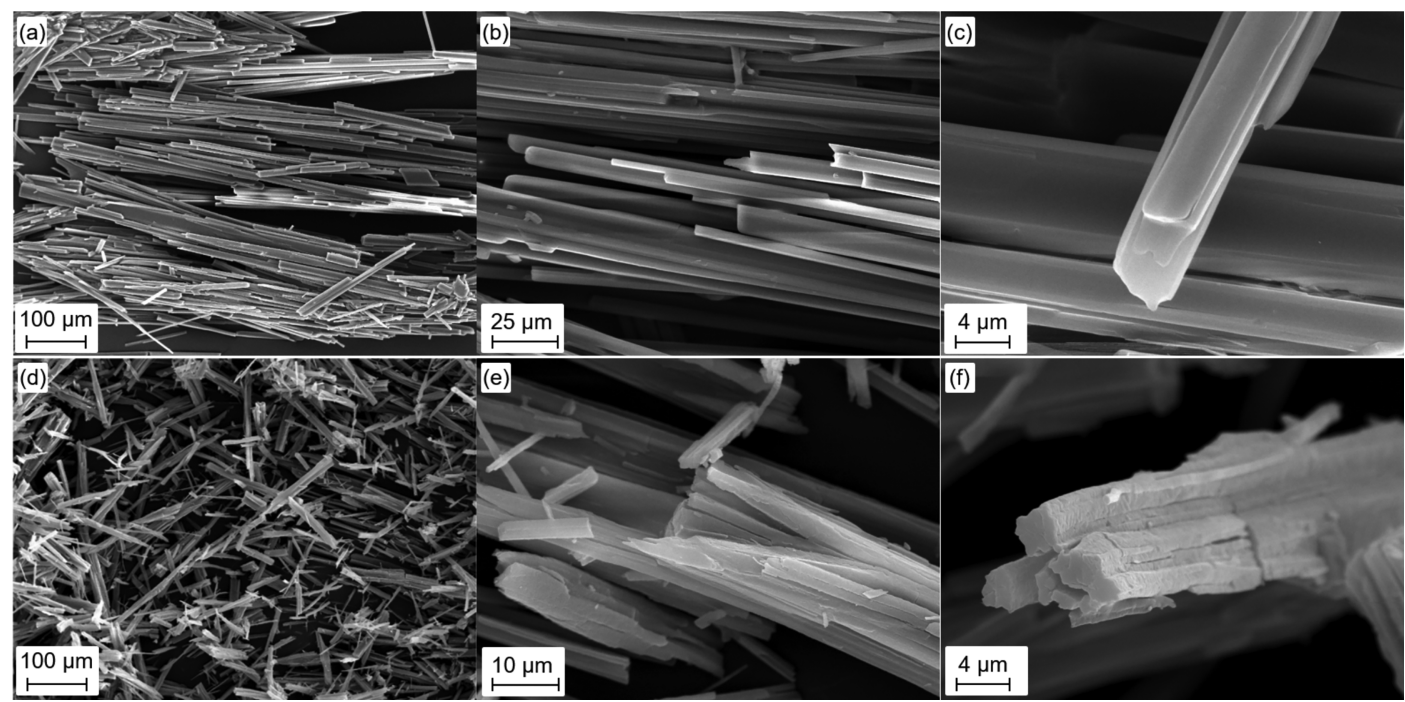

Figure 1. SEM images of the starting material $\mathrm{Ca}\left(\mathrm{CH}_{3} \mathrm{COO}\right)_{2} \cdot \mathrm{H}_{2} \mathrm{O}(\mathrm{a}-\mathrm{c})$ and of the calcinated material at room temperature $\alpha-\mathrm{Ca}\left(\mathrm{CH} \mathrm{COO}_{3}\right)_{2}(\mathrm{~d}-$ f).

The acetate related atom sites were constrained by using rigid bodies in z-matrix notation. Because of the limits of the PXRD method, the acetate related hydrogen sites were omitted. A merging radius of $0.7 \AA^{31}$ was used to check for atoms situated on special positions (inversion centers) or occupying identical sites. The global optimizations were carried out several times with different starting sets of rigid bodies and ions and led to identical results within the error limits each time. For the final Rietveld refinements, ${ }^{32}$ all profile and lattice parameters were released iteratively and positions of the calcium atoms were subjected to free unconstrained refinement. The bond lengths and angles of the rigid bodies were refined, restraining them to reasonable values. The final agreement factors are listed in the Supporting Information (Table S1), the atomic coordinates and selected bond lengths are given in Table S2 and Table S3, and the fit of the whole powder pattern is shown in Figures S3 and S4. The crystallographic data have been deposited at CCDC, deposit numbers: 1999002-1999003.

Refinement of the Temperature-Dependent in situ PXRD Patterns. The temperature -dependent in situ PXRD patterns were subjected to fully weighted Rietveld refinements. The crystal structure of $\mathrm{HT}-\alpha-\mathrm{Ca}\left(\mathrm{CH}_{3} \mathrm{COO}\right)_{2}$ that was determined at $300{ }^{\circ} \mathrm{C}$ was used as the starting model for the laboratory data of the first cooling cycle starting at $310{ }^{\circ} \mathrm{C}$. All lattice parameters and the positions of the calcium cations were freely refined. The positions of all acetate related atoms were constrained by rigid bodies that were allowed to freely rotate and translate. The refined crystal structure was then used as the starting model for the next temperature step in an iterative process. This procedure was conducted for all heating and cooling cycles. The synchrotron data were refined by an analogous procedure. The volume thermal expansion coefficients and all axes expansion coefficients were calculated from the refined lattice parameters by using the PASCal software. $^{33}$

\section{RESULTS}

Phase Characterization. The crystallization of Ca$\left(\mathrm{CH}_{3} \mathrm{COO}\right)_{2} \cdot \mathrm{H}_{2} \mathrm{O}$ by diffusion of a saturated aqueous solution of calcium acetate through the pores of a terracotta vessel leads to the formation of a well crystalline material (Supporting Information, Figure S1, calculated: $\mathrm{C}=27.3 \mathrm{wt} \%, \mathrm{H}=4.6 \mathrm{wt} \%$, found: $\mathrm{C}=27.2(1)$ wt $\%, \mathrm{H}=4.5(1)$ wt $\%)$. The crystallites exhibit a pronounced needle-like morphology with lengths of up to more than $100 \mu \mathrm{m}$ (Figure 1a) and diameters of approximately $4 \mu \mathrm{m}$ (Figure 1, c). After thermal dehydration, the crystallites are considerably smaller (Figure 1d). During heating, they seem to split along the long axis, and the crystallite surface appears to be rougher after the thermal treatment (Figure 1e,f).

The diffraction pattern of $\alpha-\mathrm{Ca}\left(\mathrm{CH}_{3} \mathrm{COO}\right)_{2}$ that was recorded at room temperature (Figure $2 \mathrm{a}$ ) is in good agreement with the reference data given by Panzer $^{21}$ (red lines). Some peak intensities differ, which is attributed to the fact that the reference data correspond to flat plate (Bragg-Brentano Geometry)

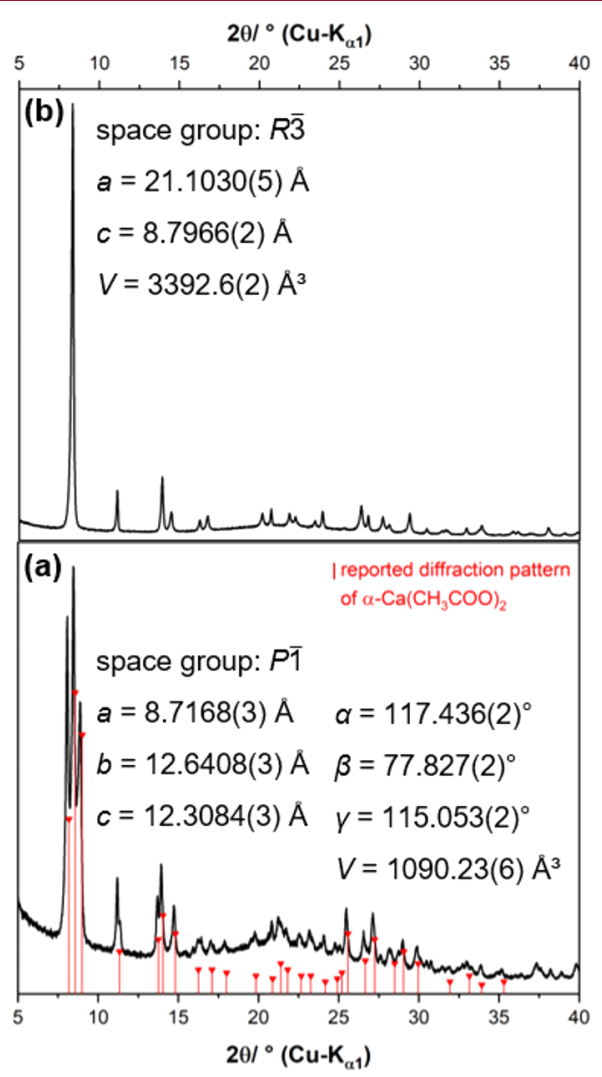

Figure 2. PXRD patterns of $\alpha-\mathrm{Ca}\left(\mathrm{CH}_{3} \mathrm{COO}\right)_{2}$ at room temperature (a) and at $310{ }^{\circ} \mathrm{C}(\mathrm{b})$ including reference data of $\alpha-\mathrm{Ca}\left(\mathrm{CH}_{3} \mathrm{COO}\right)_{2}{ }^{21}$ space group symmetries and lattice parameters obtained by LSI indexing. ${ }^{27}$ 


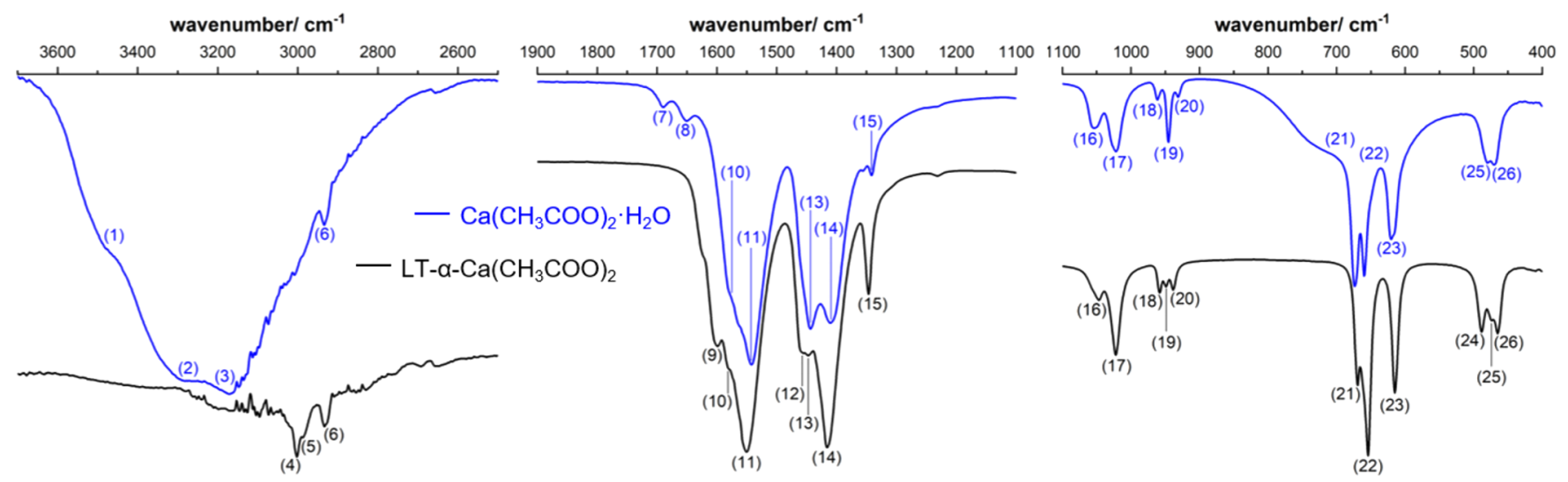

Figure 3. Excerpts form the IR-spectra of the starting material, $\mathrm{Ca}\left(\mathrm{CH}_{3} \mathrm{COO}\right)_{2} \cdot \mathrm{H}_{2} \mathrm{O}$ (blue line) and the calcinated material, $\mathrm{LT}-\alpha$-Ca( $\left.\mathrm{CH} \mathrm{H}_{3} \mathrm{COO}\right)_{2}$ (black line); the complete IR-spectrum is presented in the Supporting Information (Figure S5), and a tentative band assignment is given in Table 1.

measurements and therefore may be influenced by preferred orientation effects. There are also additional Bragg-peaks present in the recorded diffraction pattern. As they cannot be assigned to any known byproduct such as $\mathrm{Ca}\left(\mathrm{CH}_{3} \mathrm{COO}\right)_{2}$. $\mathrm{H}_{2} \mathrm{O},{ }^{18} \beta-\mathrm{Ca}\left(\mathrm{CH}_{3} \mathrm{COO}\right)_{2}{ }^{21}$ or $\mathrm{Ca}\left(\mathrm{CH}_{3} \mathrm{COO}\right)_{2} \cdot 1 / 2 \mathrm{H}_{2} \mathrm{O}$, ${ }^{23}$ and as the elemental analysis indicated the presence of pure anhydrous calcium acetate (calculated: $\mathrm{C}=30.4 \mathrm{wt} \%, \mathrm{H}=$ 3.8 wt $\%$, found: $\mathrm{C}=30.4(1)$ wt $\%, \mathrm{H}=3.8(1)$ wt $\%)$, we included all measured reflections into the indexing process, which led to a triclinic unit cell of 1090.23(6) $\AA^{3}$ and the lattice parameters given in Figure 2a. Heating of the solid to $310{ }^{\circ} \mathrm{C}$ led to a drastic change in the diffraction pattern (Figure 2b). Indexing of the diffraction pattern revealed a rhombohedral unit cell with a tripled volume and lattice parameters as given in Figure $2 b$. The $c$-axis $(8.7966(2) \AA)$ of the rhombohedral cell corresponds to the $a$-axis $(8.7168(3) \AA)$ of the triclinic one. As a consequence, there is a low- and a high-temperature modification of $\alpha-\mathrm{Ca}\left(\mathrm{CH}_{3} \mathrm{COO}\right)_{2}$. A comparison with the literature data revealed that $\mathrm{HT}-\alpha-\mathrm{Ca}\left(\mathrm{CH}_{3} \mathrm{COO}\right)_{2}$ ("high temperature" $\alpha$-Ca $\left.\left(\mathrm{CH}_{3} \mathrm{COO}\right)_{2}\right)$ has already been observed as an intermediate during the thermal decomposition of both $\mathrm{Ca}\left(\mathrm{CH}_{3} \mathrm{COO}\right)_{2} \cdot 1 / 2 \mathrm{H}_{2} \mathrm{O}^{23}$ and $\mathrm{Ca}_{3}\left(\mathrm{CH}_{3} \mathrm{COO}\right)_{4}(\mathrm{HCOO})_{2}$. $4 \mathrm{H}_{2} \mathrm{O} .^{10}$

IR spectroscopy at ambient conditions additionally proves the complete release of water molecules after the calcination process, as all water related $\mathrm{O}-\mathrm{H}$ stretching and bending modes disappear in the spectrum of the calcinated material (Figure 3, (1-3), (7), (8)). Except for the water related bands, the IR-spectra of $\mathrm{Ca}\left(\mathrm{CH}_{3} \mathrm{COO}\right)_{2} \cdot \mathrm{H}_{2} \mathrm{O}$ and LT- $\alpha$-Ca$\left(\mathrm{CH}_{3} \mathrm{COO}\right)_{2}$ are very similar. The comparatively small splitting of the most intense symmetrical and antisymmetrical carboxylate related $\mathrm{C}-\mathrm{O}$ stretching modes (Figure 3, Table 1, (11), (14)) of $\Delta \nu=134 \mathrm{~cm}^{-1}$ indicates that the majority of the acetate anions in $\mathrm{LT}-\alpha-\mathrm{Ca}\left(\mathrm{CH}_{3} \mathrm{COO}\right)_{2}$ exhibit a bidentate and bridging coordination behavior. ${ }^{34}$ However, additional asymmetrical C$\mathrm{O}$ stretching modes of lower intensities at higher wavenumbers (Figure 3, Table 1, (9), (10)) point to monodentate coordination behavior of some of the acetate groups in the crystal structures of the anhydrous calcium acetates. The overall splitting of the $\mathrm{C}-\mathrm{O}$ and $\mathrm{C}-\mathrm{C}$ related stretching modes indicates the presence of at least three to four symmetrically independent acetate anions in the crystal structure of LT- $\alpha$ $\mathrm{Ca}\left(\mathrm{CH}_{3} \mathrm{COO}\right)_{2}$.

Temperature-dependent in situ PXRD and DTA analysis were employed to investigate the transformations between HT- and
Table 1. Band Positions, Shapes, and Tentative Assignments in the IR Spectra of the Starting Material, $\mathrm{Ca}\left(\mathrm{CH}_{3} \mathrm{COO}\right)_{2}{ }^{*}$ $\mathrm{H}_{2} \mathrm{O}$, and the Calcinated Material, LT- $\alpha-\mathrm{Ca}\left(\mathrm{CH}_{3} \mathrm{COO}\right)_{2}$, According to Literature Data ${ }^{35-38}$

\begin{tabular}{|c|c|c|c|}
\hline $\begin{array}{l}\text { band } \\
\text { no. }\end{array}$ & $\begin{array}{l}\mathrm{Ca}\left(\mathrm{CH}_{3} \mathrm{COO}\right)_{2} \cdot \mathrm{H}_{2} \mathrm{O} \\
\text { position } / \mathrm{cm}^{-1}\end{array}$ & $\begin{array}{c}\mathrm{LT}-\alpha- \\
\mathrm{Ca}\left(\mathrm{CH}_{3} \mathrm{COO}\right)_{2} \\
\text { position } / \mathrm{cm}^{-1}\end{array}$ & assignment \\
\hline (1) & $3470, \mathrm{br}$ & & $\nu(\mathrm{O}-\mathrm{H})\left[\mathrm{H}_{2} \mathrm{O}\right]$ \\
\hline (2) & $3270, \mathrm{br}$ & & \\
\hline (3) & 3167, br & & \\
\hline (4) & & $3003, \mathrm{~s}$ & $\nu(\mathrm{C}-\mathrm{H})\left[\mathrm{CH}_{3}\right]$ \\
\hline (5) & & 2984, sh & \\
\hline (6) & $2933, \mathrm{~m}$ & $2929, \mathrm{~m}$ & \\
\hline (7) & $1690, \mathrm{~m}$ & & $\delta(\mathrm{O}-\mathrm{H})\left[\mathrm{H}_{2} \mathrm{O}\right]$ \\
\hline (8) & $1652, \mathrm{~m}$ & & \\
\hline (9) & & $1601, \mathrm{~m}$ & $\nu(\mathrm{C}-\mathrm{O})_{\text {as }}$ \\
\hline (10) & 1575, sh & $1581, \mathrm{sh}$ & \\
\hline (11) & $1542, \mathrm{~m}$ & $1550, \mathrm{~m}$ & \\
\hline (12) & & $1454, \mathrm{sh}$ & $\nu(\mathrm{C}-\mathrm{O})_{\mathrm{s}}$ \\
\hline (13) & $1444, \mathrm{~m}$ & $1447, \mathrm{~m}$ & \\
\hline (14) & $1409, \mathrm{~m}$ & $1416, \mathrm{~m}$ & \\
\hline (15) & $1341, \mathrm{~s}$ & $1347, \mathrm{~s}$ & $\delta(\mathrm{C}-\mathrm{H})\left[\mathrm{CH}_{3}\right]$ \\
\hline (16) & $1054, \mathrm{~m}$ & $1048, \mathrm{~m}$ & $\rho(\mathrm{C}-\mathrm{H})\left[\mathrm{CH}_{3}\right]$ \\
\hline (17) & $1024, \mathrm{~m}$ & $1022, \mathrm{~m}$ & \\
\hline (18) & $961, \mathrm{~s}$ & $958, \mathrm{~m}$ & $\nu(\mathrm{C}-\mathrm{C})$ \\
\hline (19) & $945, \mathrm{~s}$ & $948, \mathrm{~m}$ & \\
\hline (20) & $931, \mathrm{~s}$ & $938, \mathrm{~m}$ & \\
\hline$(21)$ & $674, s$ & $670, \mathrm{~s}$ & $\delta(\mathrm{O}-\mathrm{C}-\mathrm{O})$ \\
\hline (22) & $659, \mathrm{~s}$ & $654, \mathrm{~s}$ & \\
\hline (23) & $618, \mathrm{~m}$ & $615, \mathrm{~s}$ & \\
\hline (24) & & $488, \mathrm{~m}$ & $\begin{array}{c}\nu, \rho, \omega(\mathrm{Ca}-\mathrm{O}) \\
\text { lattice modes }\end{array}$ \\
\hline (25) & 479, sh & 474, sh & \\
\hline (26) & $471, \mathrm{~m}$ & $465, \mathrm{~m}$ & \\
\hline
\end{tabular}

LT- $\alpha-\mathrm{Ca}\left(\mathrm{CH}_{3} \mathrm{COO}\right)_{2}$ (Figure 4$)$. The transformation starts between 150 and $170{ }^{\circ} \mathrm{C}$ and is completely reversible. LT- $\alpha$ $\mathrm{Ca}\left(\mathrm{CH}_{3} \mathrm{COO}\right)_{2}$ transforms endothermically into the hightemperature form (Figure $4 \mathrm{~b}$ ). while heating and cooling of the low-temperature form a pronounced shift of the Bragg peaks can be observed (Figure 4a), which indicates a strong thermal expansion.

Crystal Structure Description. LT- $\alpha-\mathrm{Ca}\left(\mathrm{CH}_{3} \mathrm{COO}\right)_{2}$ crystallizes in a centrosymmetric triclinic lattice with six formula units per unit cell and all atoms located on general positions. Hence, there are three symmetrically independent calcium sites 


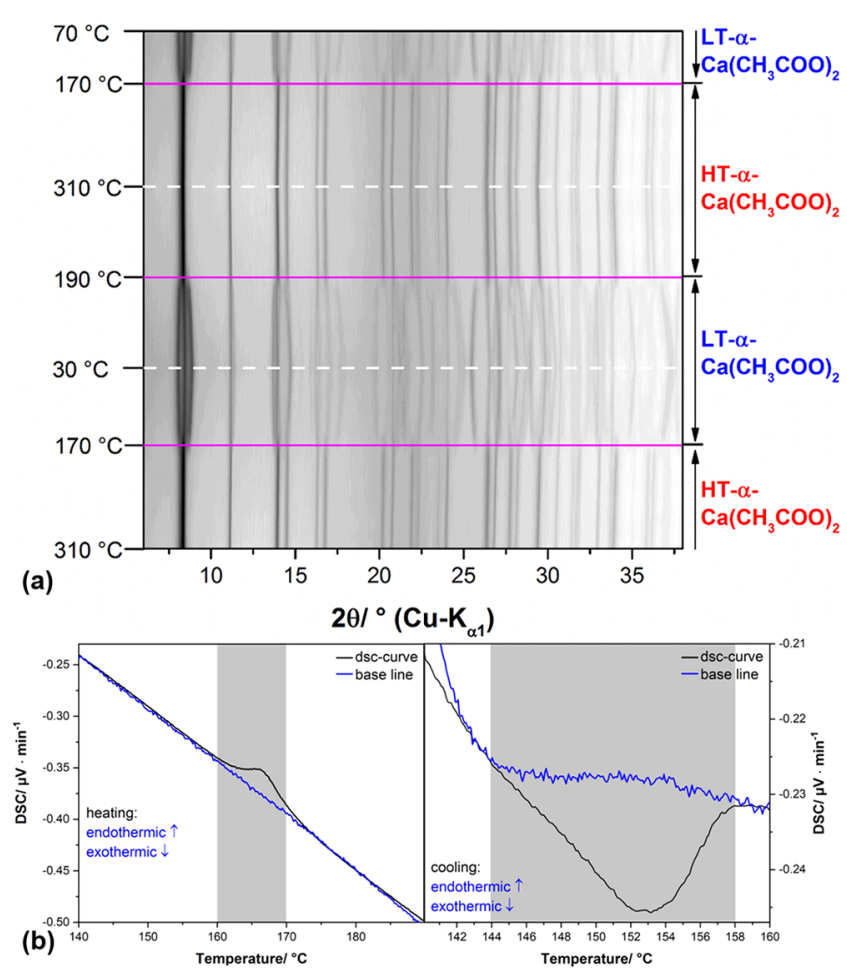

Figure 4. Temperature-dependent in situ PXRD patterns of $\alpha$ $\mathrm{Ca}\left(\mathrm{CH}_{3} \mathrm{COO}\right)_{2}$ during heating and cooling cycles (a) and DTA curves during heating (b) and cooling (c); in the gray highlighted temperature intervals, the phase transition occurs.

that are coordinated by acetate related oxygen atoms. Two of these sites, $\mathrm{Ca}(1)$ and $\mathrm{Ca}(3)$, exhibit a 7 -fold coordination sphere with acetate anions coordinating in both a mono- and bidentate fashion (Figure 5a). The other calcium site, $\mathrm{Ca}(2)$, shows a distorted octahedral coordination sphere with acetate anions coordinating exclusively in a monodentate way. HT- $\alpha$ $\mathrm{Ca}\left(\mathrm{CH}_{3} \mathrm{COO}\right)_{2}$ crystallizes in a centrosymmetric rhombohedral lattice with 18 formula units per unit cell and also all atoms located on general positions. Because of the higher space group symmetry, all calcium sites are symmetrically equivalent in the high-temperature phase. Seven acetate related oxygen atoms coordinate the calcium cation, with one acetate coordinating in a bidentate way and all other acetates showing monodentate coordination (Figure $5 \mathrm{~b}$ ). Acetate anions bridge neighboring calcium cations forming channel-like motifs of 12 edge sharing calcium carboxylate polyhedra in both structures. In the crystal structure of LT- $\alpha-\mathrm{Ca}\left(\mathrm{CH}_{3} \mathrm{COO}\right)_{2}$, these channels run in $a$ direction, and the 12-member rings are not completely closed, as neighboring $\left[\mathrm{CaO}_{6}\right]$-octahedra are bridged by acetate anions but not in an edge sharing way (Figure 5c, blue polyhedra). This is well reflected by the $\mathrm{Ca}(2)-\mathrm{Ca}(1 / 2 / 3)$ distances. Whereas the separation between $\mathrm{Ca}(2)$ and $\mathrm{Ca}(1)$ or $\mathrm{Ca}(3)$ is comparatively short with 3.89(1) Å and 3.72(1) Å, respectively, due to edge sharing of polyhedra, the distance between neighboring $\mathrm{Ca}(2)$ sites is with $4.68(1) \AA$ considerably larger. In the structure of the high-temperature phase, the channels are completely closed, as all calcium-carboxylate polyhedra are now sharing edges (Figure $5 \mathrm{~d}$ ). The distance between the calcium sites situated in polyhedra that become edge sharing after the phase transition shortens from 4.68(1) $\AA$ to $4.45(1) \AA$, even despite heating.

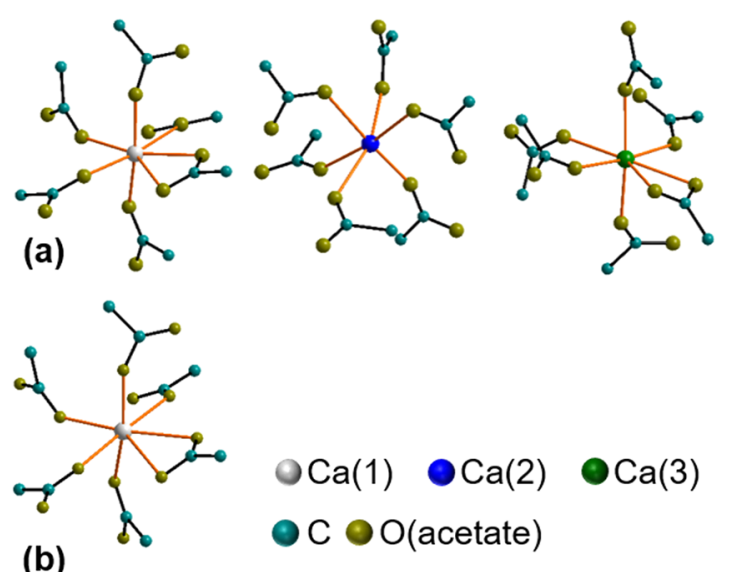

(b)
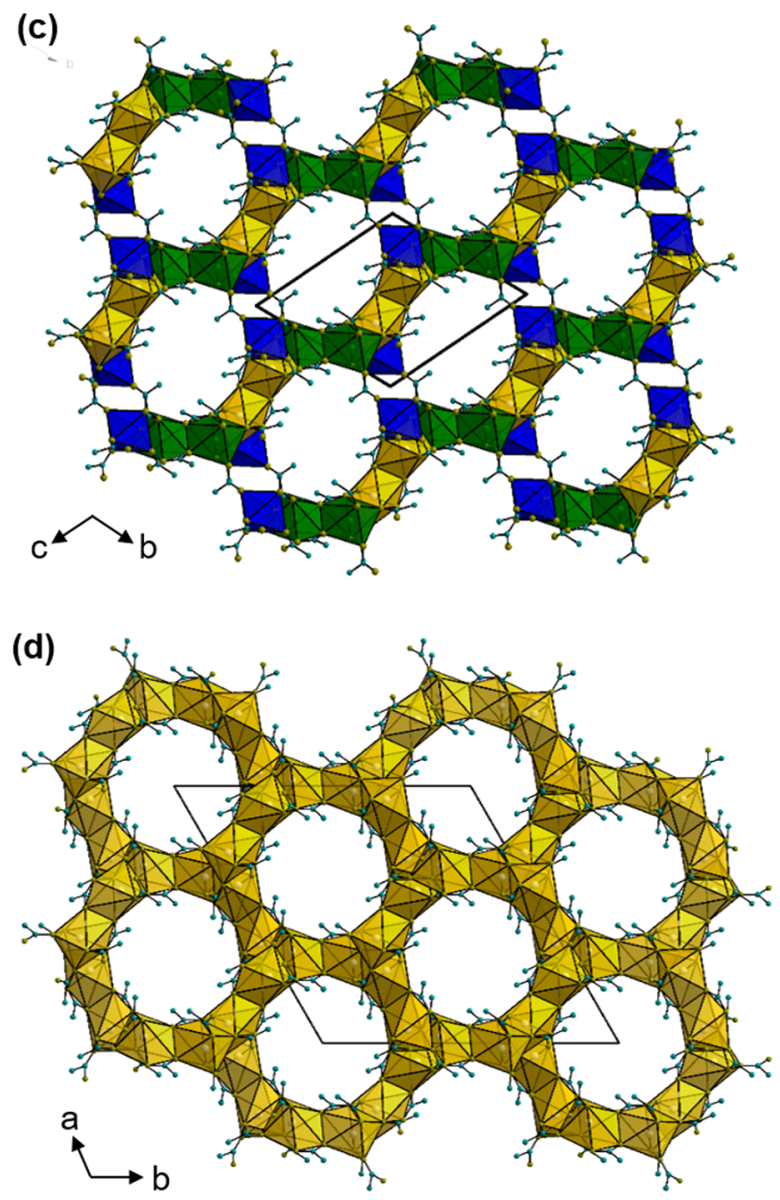

Figure 5. Calcium coordination in (a) LT- $\alpha-\mathrm{Ca}\left(\mathrm{CH}_{3} \mathrm{COO}\right)_{2}$ and (b) $\mathrm{HT}-\alpha-\mathrm{Ca}\left(\mathrm{CH}_{3} \mathrm{COO}\right)_{2}$ and packing diagrams of (c) LT- $\alpha$-Ca$\left(\mathrm{CH}_{3} \mathrm{COO}\right)_{2}$ and (d) $\mathrm{HT}-\alpha-\mathrm{Ca}\left(\mathrm{CH}_{3} \mathrm{COO}\right)_{2}$ with $\mathrm{Ca}(1)$ polyhedra presented in yellow, $\mathrm{Ca}(2)$ polyhedra presented in green and $\mathrm{Ca}(3)$ polyhedra presented in blue.

Acetate related methyl groups are situated within the channels in the crystal structures of the $\alpha-\mathrm{Ca}\left(\mathrm{CH}_{3} \mathrm{COO}\right)_{2}$ phases (Figure $6)$. The effective size of the channels cannot be determined directly from the crystal structure, since due to the limits of the PXRD method, we were not able to determine the positions of the hydrogen atoms. In addition, it is very likely that the methyl group is disordered, especially in the crystal structure of HT- $\alpha$ $\mathrm{Ca}\left(\mathrm{CH}_{3} \mathrm{COO}\right)_{2}$, which was determined at $300{ }^{\circ} \mathrm{C}$. Therefore, we decided to use the distance between the methyl related carbon atom and the center of the channels (Figure 6, magenta 


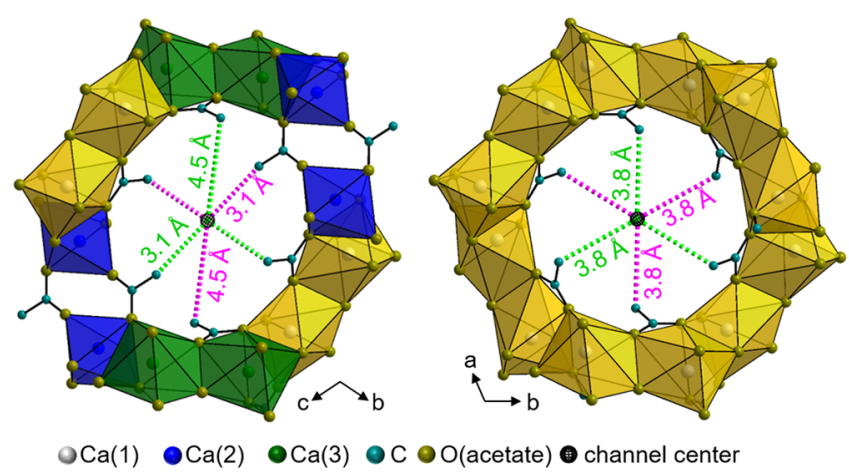

Figure 6. Comparison of the channel motifs and radii (indicated by distances of the methyl related carbon atoms and the channel centers) in the crystal structures of LT- $\alpha-\mathrm{Ca}\left(\mathrm{CH}_{3} \mathrm{COO}\right)_{2}$ (left) and HT- $\alpha$ $\mathrm{Ca}\left(\mathrm{CH}_{3} \mathrm{COO}\right)_{2}$ (right) with $\mathrm{Ca}(1)$ polyhedra presented in yellow, $\mathrm{Ca}(2)$ polyhedra presented in green, and $\mathrm{Ca}(3)$ polyhedra presented in blue. The methyl related carbon atoms situated within the figure plane are indicated by green dashed lines, the methyl related carbon atoms exhibiting an offset with respect to the figure plane are indicated by magenta dashed lines.

and green dashed lines) as a measure of the channel radius, and it should be noted that the real channel radii are up to $1 \AA$ smaller. In the crystal structure of LT- $\alpha-\mathrm{Ca}\left(\mathrm{CH}_{3} \mathrm{COO}\right)_{2}$, the channels exhibit an elliptical shape. This results in distances between the channel center and methyl related carbon atoms of 3.1 and $4.5 \AA$. Because of the trigonal lattice symmetry of the high-temperature phase, the channels show a circular shape with all methyl related carbon atoms being located at a distance of $3.8 \AA$ to the channel center. The channels are not accessible for any gas loading as it is shown by the comparatively small BET surface of $0.47(8) \mathrm{m}^{2} / \mathrm{g}$, and the isotherms (Supporting Information, Figures S 6 and S 7) can be classified as type II, which is typically found for nonporous materials. ${ }^{39}$

Thermal Expansion. The thermal expansion of $\alpha$-Ca$\left(\mathrm{CH}_{3} \mathrm{COO}\right)_{2}$ was investigated by temperature-dependent in situ laboratory and synchrotron PXRD measurements (Figure 7a, open and filled symbols). The unit cell volume of LT- $\alpha$ $\mathrm{Ca}\left(\mathrm{CH}_{3} \mathrm{COO}\right)_{2}$ shows a comparatively big expansion, as it expands by heating from 25 to $150{ }^{\circ} \mathrm{C}(\Delta T=125 \mathrm{~K})$ by more than $1.6 \%$ (Figure $7 \mathrm{a}$, blue symbols). After the phase transition, both the unit cell volume and the crystallographic density show a discontinuous jump, which is indicative for a first-order phase transition. This is additionally confirmed by the peaks observed in the DTA curve (Figure $4 b, c)$. The thermal expansion of HT$\alpha$ - $\mathrm{Ca}\left(\mathrm{CH}_{3} \mathrm{COO}\right)_{2}$ progresses considerably more slowly, as heating from 175 to $300{ }^{\circ} \mathrm{C}(\Delta T=125 \mathrm{~K})$ only leads to a volume expansion of $0.9 \%$ (Figure $7 \mathrm{a}$, red symbols). Accordingly, the linear thermal expansion coefficient, $\alpha$, of the low-temperature phase was calculated as being doubled in comparison to that one of the high-temperature phase (Table 2 ). Detailed analyses of the principal directions of the thermal

Table 2. Volume Expansion Coefficients and All Axes Expansion Coefficients of LT- and HT- $\alpha-\mathrm{Ca}\left(\mathrm{CH}_{3} \mathrm{COO}\right)_{2}{ }^{a}$

\begin{tabular}{|c|c|c|c|c|c|}
\hline axes & $\alpha / 10^{-6} \mathrm{~K}^{-1}$ & $\sigma(\alpha) / 10^{-6} \mathrm{~K}^{-1}$ & $a$ & $b$ & $c$ \\
\hline \multicolumn{6}{|c|}{$\mathrm{LT}-\alpha-\mathrm{Ca}\left(\mathrm{CH}_{3} \mathrm{COO}\right)_{2}$} \\
\hline $\mathrm{X}_{1}$ & -94.8827 & 5.612 & 0.1141 & 0.6001 & 0.7917 \\
\hline $\mathrm{X}_{2}$ & 20.8118 & 1.0435 & 0.9893 & 0.1399 & -0.0424 \\
\hline $\mathrm{X}_{3}$ & 217.7281 & 8.4507 & -0.2997 & -0.8808 & 0.3665 \\
\hline $\mathrm{V}$ & 147.1779 & 5.2854 & & & \\
\hline \multicolumn{6}{|c|}{$\mathrm{HT}-\alpha-\mathrm{Ca}\left(\mathrm{CH}_{3} \mathrm{COO}\right)_{2}$} \\
\hline $\mathrm{X}_{1}$ & 20.2163 & 0.2807 & 0.8179 & 0.5753 & 0 \\
\hline $\mathrm{X}_{2}$ & 20.2163 & 0.2807 & -0.2994 & 0.9541 & 0 \\
\hline $\mathrm{X}_{3}$ & 31.7141 & 0.7337 & 0 & 0 & 1 \\
\hline $\mathrm{V}$ & 72.4323 & 0.2288 & & & \\
\hline
\end{tabular}

${ }^{a} \alpha$ is the linear coefficient of the thermal expansion with $\sigma(\alpha)$ being the corresponding estimated standard deviation, a, b, and $c$ are the projections of the principal directions $\mathrm{X}_{n}$ on the unit cell axes. Plots of the thermal expansion along the principal axes and of the overall volume expansion are given in Figure S8 of the Supporting Information.

expansion reveal that LT- $\alpha$ - $\mathrm{Ca}\left(\mathrm{CH}_{3} \mathrm{COO}\right)_{2}$ expands anisotropically. The material shows a large positive thermal expansion in one direction $\left(\alpha\left(\mathrm{X}_{3}\right)=217(9) \times 10^{-6} \mathrm{~K}\right.$, Table 2$)$, whereas the expansion in an orthogonal direction is negative $\left(\alpha\left(\mathrm{X}_{1}\right)=\right.$ $-95(6) \times 10^{-6} \mathrm{~K}$, Figure $7 \mathrm{~b}$, red and blue grids). In contrast, $\mathrm{HT}-\alpha-\mathrm{Ca}\left(\mathrm{CH}_{3} \mathrm{COO}\right)_{2}$ exhibits positive thermal expansion, exclusively (Figure 7c), with similar thermal expansion coefficients for all principal axes (Table 2) and therefore expands almost isotropically.
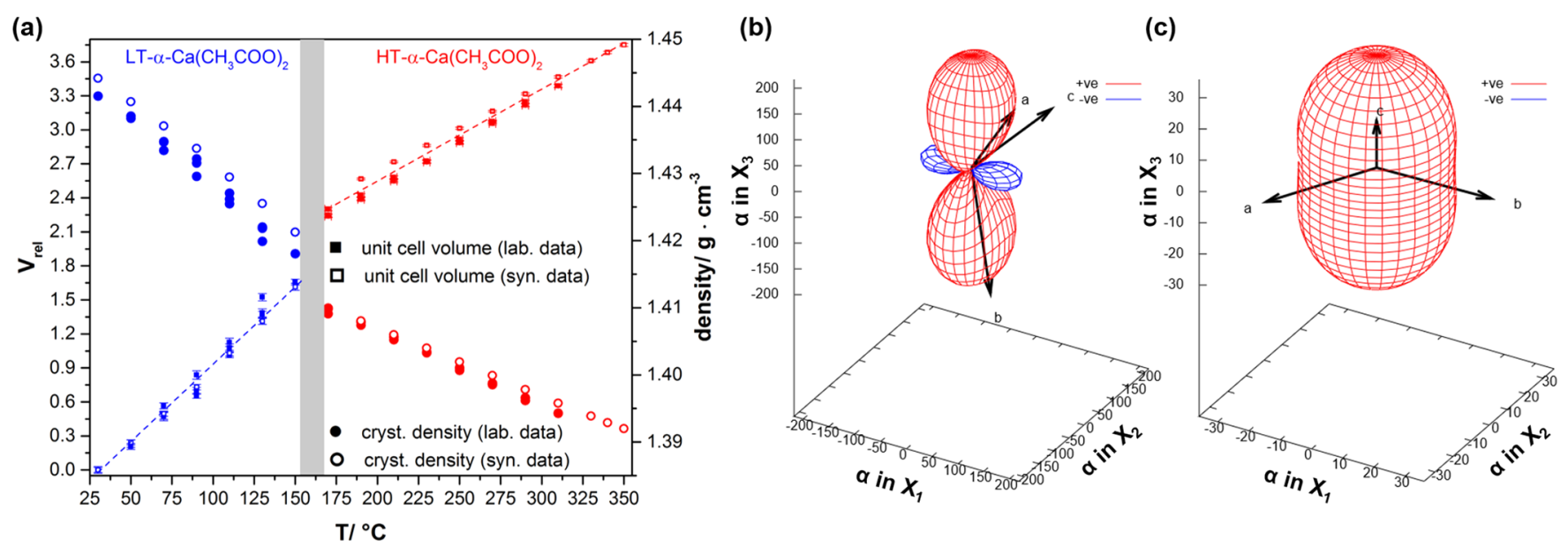

Figure 7. Evolution of the lattice parameters and the crystallographic density of LT- and HT-HT- $\alpha$-Ca $\left(\mathrm{CH}_{3} \mathrm{COO}\right)_{2}$ upon heating (a), plots showing the variation of the thermal expansion coefficient $\alpha$ with the principal directions $\mathrm{X}_{1}, \mathrm{X}_{2}$, and $\mathrm{X}_{3}($ Table 2$)$ of LT- (b) and HT- $\alpha$ - $\mathrm{Ca}\left(\mathrm{CH}_{3} \mathrm{COO}\right)_{2}(\mathrm{c})$; red lines indicate positive and blue lines negative thermal expansion. 


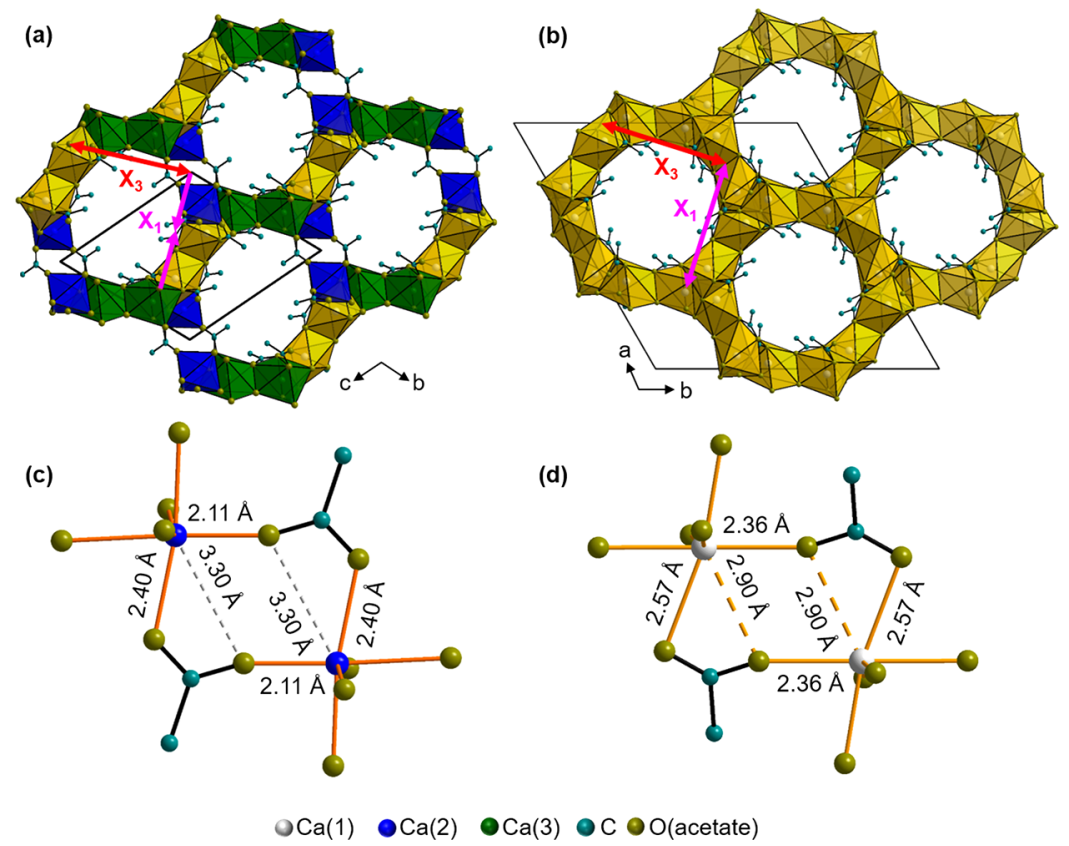

Figure 8. Illustration of the orientation of the principal axes, $\mathrm{X}_{1}$ and $\mathrm{X}_{3}$ (Table 2), of the thermal expansion of LT- (a) and HT- $\alpha$-Ca $\left(\mathrm{CH} \mathrm{H}_{3} \mathrm{COO}\right)_{2}(\mathrm{~b})$ in their crystal structures, changes in the Ca-coordination during the phase transition from LT- (c) to HT- $\alpha$ - $\mathrm{Ca}\left(\mathrm{CH}_{3} \mathrm{COO}\right)_{2}(\mathrm{~d})$.

A closer look into the crystal structures of $\alpha-\mathrm{Ca}\left(\mathrm{CH}_{3} \mathrm{COO}\right)_{2}$ provides an explanation of its anisotropic thermal expansion and the change in the expansion behavior after the phase transition. The $X_{1}$ and $X_{3}$ axes (Figure 8a,b; red and magentas arrows) are oriented orthogonally to the channels in the crystal structures, whereas the $\mathrm{X}_{2}$ axis shows parallel orientation to the channels. Accordingly, for the low-temperature phase, the absolute value for the expansion coefficient along the channel direction is the lowest, and these coefficients are within the error range identical for both LT- and HT- $\alpha-\mathrm{Ca}\left(\mathrm{CH}_{3} \mathrm{COO}\right)_{2}$ (Table 2). The negative thermal expansion, or in other words, the thermal contraction along the $\mathrm{X}_{1}$ direction, in the crystal structure of the low-temperature phase leads to a shortening of $\mathrm{Ca}(2)-\mathrm{Ca}(2)$ distances (Figure 8a, blue polyhedra) and finally makes the $\left[\mathrm{CaO}_{7}\right]$ polyhedral edge sharing after the phase transition (Figure $8 \mathrm{~b}$ ). This is also reflected by the calcium-oxygen distances. The acetate anions bridging these calcium cations are clearly coordinating in a monodentate fashion, as one of the acetate related oxygen atoms exhibits a distance of $3.30 \AA$ to one of the Ca2 sites (Figure 8c, dashed gray bond). During heating all other $\mathrm{Ca}-\mathrm{O}$ distances increase, while this distance decreases to $2.90 \AA$. Therefore, this oxygen atoms enters the coordination sphere of calcium (Figure 8d), and the incorporation of an additional ligand atom into the $\mathrm{Ca}^{2+}$-coordination sphere must be the driving force for the negative thermal expansion along the $\mathrm{X}_{1}$-axis. In the orthogonal $\mathrm{X}_{3}$-direction (Figure 8a; red arrow) LT- $\alpha-\mathrm{Ca}\left(\mathrm{CH}_{3} \mathrm{COO}\right)_{2}$ shows a considerably high thermal expansion coefficient of $218(8) 10^{-6} \mathrm{~K}^{-1}$, which severely decreases to $72(1) 10^{-6} \mathrm{~K}^{-1}$ after the phase transition (Table 2). This expansion counteracts the elliptical shape of the channels in LT- $\alpha-\mathrm{Ca}\left(\mathrm{CH}_{3} \mathrm{COO}\right)_{2}$ (Figure 6) and thus enables the increase of the lattice symmetry from $P \overline{1}$ to $R \overline{3}$. After the transition to HT- $\alpha-\mathrm{Ca}\left(\mathrm{CH}_{3} \mathrm{COO}\right)_{2}$, the principal $\mathrm{X}_{1}$ and $\mathrm{X}_{3}$ axes become symmetrically equivalent.

\section{DISCUSSION}

The crystal structures of the high- and low-temperature form of $\alpha-\mathrm{Ca}\left(\mathrm{CH}_{3} \mathrm{COO}\right)_{2}$ with their channel-like structural main motifs appear to be special, despite the fact that the overall structural knowledge of anhydrous divalent metal acetates is very limited. The crystal structures of $\beta$ - and $\gamma-\mathrm{Ca}\left(\mathrm{CH}_{3} \mathrm{COO}\right)_{2}$ are still unknown. Because of their hygroscopic behavior and their sensitivity toward hydrolysis, often only the crystal structures of the acetate hydrates, ${ }^{12,40}$ or of $\mathrm{oxy}^{41-43}$ or hydroxy acetates, ${ }^{44-46}$ as so-called "basic acetates" are known. Barium acetate, which is the only known anhydrous alkaline earth metal acetate, exhibits different structural motifs, since interconnected $\mathrm{Ba}_{4}\left(\mathrm{CH}_{3} \mathrm{COO}\right)_{8}$ units build up a three-dimensional network with much smaller channels formed by six-membered rings of barium carboxylate polyhedra. ${ }^{47}$ Anhydrous zinc(II) ${ }^{48}$ and iron(II) acetate ${ }^{49}$ crystallize as two-dimensional coordination polymers and in anhydrous chromium(II), $,^{50} \operatorname{copper}(\mathrm{II}),{ }^{51}$ molybdenum(II), ${ }^{52}$ and rhodium(II) ${ }^{53}$ dinuclear $\mathrm{M}_{2}\left(\mathrm{CH}_{3} \mathrm{COO}\right)_{4}$ paddle wheel complexes form one-dimensional chains, whereas the crystal structures of anhydrous manganese(II), cobalt(II), and nickel(II) acetate are still unknown.

The thermal expansion behavior of LT- $\alpha-\mathrm{Ca}\left(\mathrm{CH}_{3} \mathrm{COO}\right)_{2}$ that completely changes after the transformation into the hightemperature phase is remarkable. A large positive thermal expansion is well-known for coordination compounds with more complex carboxylate ligands such as $\left[\mathrm{Cu}_{2}\right.$ (benzoate) $4\left(3^{\prime}\right.$ fluoro-4-styrylpyridine) $\left.)_{2}\right],{ }^{54}$ which shows a volumetric thermal expansion of $285.7 \times 10^{-6} \cdot \mathrm{K}^{-1}$. It is uncommon for solids to exhibit both negative and positive thermal expansion coefficients simultaneously. There are some examples of metal organic frameworks such as [ $\mathrm{Zn}$ (trans-2-(4-pyridyl)-4-vinylbenzoate) $)_{2}$ ] $\mathrm{DMF}^{55}$ or $[\mathrm{Cd}(3$-(pyridin-4-yl)benzoate)(4-(pyridin-4-yl)benzoate)].DMF/DMA ${ }^{56}$ showing this effect, but they are all built from much more complex ligand systems than simple acetate anions. A prominent and comparatively simple representative for colossal positive and negative thermal expansion is $\mathrm{Ag}_{3}\left[\mathrm{Co}(\mathrm{CN})_{6}\right]{ }^{57}$ In this case, weak argentophilic 
$\left(\mathrm{Ag}^{+} \cdots \mathrm{Ag}+\right)$ interactions and the flexible Co-CN-Ag-NC-Co interactions govern the thermal behavior, whereas in $\alpha$-calcium acetate the incorporation of an additional ligand atom into the $\mathrm{Ca}^{2+}$-coordination sphere is the driving force for the anisotropic thermal expansion.

\section{CONCLUSIONS}

Thermal dehydration of $\mathrm{Ca}\left(\mathrm{CH}_{3} \mathrm{COO}\right)_{2} \cdot \mathrm{H}_{2} \mathrm{O}$ and additional heating to $300{ }^{\circ} \mathrm{C}$ lead to the formation of the $\alpha$-polymorph of anhydrous calcium acetate. This polymorph exhibits a high- and low-temperature form, with the latter matching the PXRD reference data for $\alpha-\mathrm{Ca}\left(\mathrm{CH}_{3} \mathrm{COO}\right)_{2}$. The phase transition between the high- and low-temperature form is completely reversible. $\mathrm{LT}-\alpha-\mathrm{Ca}\left(\mathrm{CH}_{3} \mathrm{COO}\right)_{2}$ crystallizes in a primitive, triclinic lattice, whereas $\mathrm{HT}-\alpha-\mathrm{Ca}\left(\mathrm{CH}_{3} \mathrm{COO}\right)_{2}$ exhibits a rhombohedral unit cell with tripled volume. In both crystal structures, edge sharing polyhedra of calcium cations and acetate anions that coordinate in both a mono- and bidentate way build up channel-like motifs. The only difference between the crystal structures is the coordination number. In HT- $\alpha$-Ca$\left(\mathrm{CH}_{3} \mathrm{COO}\right)_{2}$, all calcium cations are coordinated by seven acetate related oxygen atoms, whereas in the low-temperature form one out of three calcium sites exhibits only a 6-fold oxygen coordination. During the phase transition, an additional acetate related oxygen atom enters this coordination sphere, and the elliptical channels of the low-temperature form become circular. This leads to the presence of both negative and positive thermal expansion along different principal axes in the crystal structure of LT- $\alpha-\mathrm{Ca}\left(\mathrm{CH}_{3} \mathrm{COO}\right)_{2}$. Therefore, the cheap and easily accessible $\alpha-\mathrm{Ca}\left(\mathrm{CH}_{3} \mathrm{COO}\right)_{2}$ shows interesting thermal properties and a flexibility in the coordination sphere of the cation, which opens up potential usage for different applications by further modifications and engineering on its crystal structure.

\section{ASSOCIATED CONTENT}

\section{SI Supporting Information}

The Supporting Information is available free of charge at https://pubs.acs.org/doi/10.1021/acs.cgd.0c00563.

Crystallographic and Rietveld refinement data of LT- and $\mathrm{HT}-\alpha-\mathrm{Ca}\left(\mathrm{CH}_{3} \mathrm{COO}\right)_{2}$. Complete IR spectrum of LT- $\alpha$ $\mathrm{Ca}\left(\mathrm{CH}_{3} \mathrm{COO}\right)_{2} \cdot \mathrm{CO}_{2}$-adsorption and desorption curves of LT- $\alpha-\mathrm{Ca}\left(\mathrm{CH}_{3} \mathrm{COO}\right)_{2}$. Plots of the thermal expansion along the principal axes and of the overall volume expansion of LT- and HT- $\alpha-\mathrm{Ca}\left(\mathrm{CH}_{3} \mathrm{COO}\right)_{2}$ (PDF)

\section{Accession Codes}

CCDC 1999002-1999003 contain the supplementary crystallographic data for this paper. These data can be obtained free of charge via www.ccdc.cam.ac.uk/data_request/cif, or by emailing data_request@ccdc.cam.ac.uk, or by contacting The Cambridge Crystallographic Data Centre, 12 Union Road, Cambridge CB2 1EZ, UK; fax: +44 1223336033.

\section{AUTHOR INFORMATION}

\section{Corresponding Author}

Sebastian Bette - Max Planck Institute for Solid State Research, 70569 Stuttgart, Germany; State Academy of Art and Design, 70191 Stuttgart, Germany; Institute for Inorganic Chemistry, University of Stuttgart, 70569 Stuttgart, Germany; 이이.org/ 0000-0003-3575-0517; Email: S.Bette@fkf.mpg.de

\section{Authors}

Gerhard Eggert - State Academy of Art and Design, 70191 Stuttgart, Germany

Sebastian Emmerling - Max Planck Institute for Solid State Research, 70569 Stuttgart, Germany; Department of Chemistry, Ludwig Maximilian University of Munich, 81377 Munich, Germany

Martin Etter - Deutsches Elektronen-Synchtrotron (DESY), 22607 Hamburg, Germany

Thomas Schleid - Institute for Inorganic Chemistry, University of Stuttgart, 70569 Stuttgart, Germany

Robert E. Dinnebier - Max Planck Institute for Solid State Research, 70569 Stuttgart, Germany

Complete contact information is available at:

https://pubs.acs.org/10.1021/acs.cgd.0c00563

\section{Funding}

DFG project "In search of structure" (Grant EG 137/9-1).

Notes

The authors declare no competing financial interest.

\section{ACKNOWLEDGMENTS}

Marie-Louise Schreiber is gratefully acknowledged for performing the elemental analyses and the IR-spectroscopy measurements, Viola Duppel for taking the SEM-images, and Maxwell W. Terban for integrating the 2D diffraction data (all: Max Planck Institute for Solid State Research). The Max Planck Society provided open access funding.

\section{ABBREVIATIONS}

HT- $\alpha-\mathrm{Ca}\left(\mathrm{CH}_{3} \mathrm{COO}\right)_{2}$, high temperature $\alpha-\mathrm{Ca}\left(\mathrm{CH}_{3} \mathrm{COO}\right)_{2}$; LT- $\alpha$ - $\mathrm{Ca}\left(\mathrm{CH}_{3} \mathrm{COO}\right)_{2}$, low temperature $\alpha-\mathrm{Ca}\left(\mathrm{CH}_{3} \mathrm{COO}\right)_{2}$; PXRD, powder X-ray diffraction

\section{REFERENCES}

(1) Qunibi, W. Y.; Hootkins, R. E.; McDowell, L. L.; Meyer, M. S.; Simon, M.; Garza, R. O.; Pelham, R. W.; Cleveland, M. V. B.; Muenz, L. R.; He, D. Y.; Nolan, C. R. Treatment of hyperphosphatemia in hemodialysis patients: The Calcium Acetate Renagel Evaluation (CARE Study). Kidney Int. 2004, 65, 1914-1926.

(2) Lu, J. Y.; Carter, E.; Chung, R. A. Use of Calcium Salts for Soybean Curd Preparation. J. Food Sci. 1980, 45, 32-34.

(3) Hibbs, D. E.; Kolitsch, U.; Leverett, P.; Sharpe, J. L.; Williams, P. A. Hoganite and paceite, two new acetate minerals from the Potosi mine, Broken Hill, Australia. Mineral. Mag. 2002, 66, 459-464.

(4) Li, S.; Huskić, I.; Novendra, N.; Titi, H. M.; Navrotsky, A.; Frǐ̌̌cić, T. Mechanochemical Synthesis, Accelerated Aging, and Thermodynamic Stability of the Organic Mineral Paceite and Its Cadmium Analogue. ACS Omega 2019, 4, 5486-5495.

(5) Tennent, N. H.; Baird, T. The deterioration of Mollusca collections: identification of shell efflorescence. Stud. Conserv. 1985, 30, 73-85.

(6) Boccia Paterakis, A.; Steiger, M. Salt efflorescence on pottery in the Athenian Agora: A closer look. Stud. Conserv. 2015, 60, 172-184.

(7) Gibson, L. T.; Watt, C. M. Acetic and formic acids emitted from wood samples and their effect on selected materials in museum environments. Corros. Sci. 2010, 52, 172-178.

(8) Byne, L. F. G. The corrosion of shells in cabinets. J. Conchology 1899, 9, 172-178.

(9) Bette, S.; Eggert, G.; Fischer, A.; Stelzner, J.; Dinnebier, R. E. Characterization of a new efflorescence salt on calcareous historic objects stored in wood cabinets: $\mathrm{Ca}_{2}\left(\mathrm{CH}_{3} \mathrm{COO}\right)(\mathrm{HCOO})\left(\mathrm{NO}_{3}\right)_{2}$. $4 \mathrm{H}_{2}$ O. Corros. Sci. 2018, 132, 68-78.

(10) Bette, S.; Müller, M. X.; Eggert, G.; Schleid, T.; Dinnebier, R. E. Efflorescence on calcareous objects in museums: crystallisation, phase 
characterisation and crystal structures of calcium acetate formate phases. Dalton Trans. 2019, 48, 16062-16073.

(11) Cooksey, B. G.; Gibson, L. T.; Kennedy, A. R.; Littlejohn, D.; Stewart, L.; Tennent, N. H. Dicalcium triacetate nitrate dihydrate. Acta Crystallogr., Sect. C: Cryst. Struct. Commun. 1999, 55, 324-326.

(12) Giuseppetti, G.; Tadini, C.; Ungaretti, L. La struttura cristallina della calclacite/ Crystalline structure of a triclinic phase of the compound corresponding to calclacite, $\mathrm{Ca}\left(\mathrm{CH}_{3} \mathrm{COO}\right) \mathrm{Cl} \cdot 5 \mathrm{H}_{2} \mathrm{O}$. Period. Mineral. 1972, 41, 9-21.

(13) van Tassel, R. On the crystallography of calclacite, Ca$\left(\mathrm{CH}_{3} \mathrm{COO}\right) \mathrm{Cl} \cdot 5 \mathrm{H}_{2} \mathrm{O}$. Acta Crystallogr. 1958, 11, 745-746.

(14) Voncken, J. H. L.; Verkroost, T. W.; Van Tooren, M. M. New powder diffraction data on calclacite $\left(\mathrm{CaClC}_{2} \mathrm{H}_{3} \mathrm{O}_{2} \cdot 5 \mathrm{H}_{2} \mathrm{O}\right)$. Neues Jahrb. Mineral., Monatsh. 2001, 210-220.

(15) Wahlberg, N.; Runčevski, T.; Dinnebier, R. E.; Fischer, A.; Eggert, G.; Iversen, B. B. Crystal Structure of Thecotrichite, an Efflorescent Salt on Calcareous Objects Stored in Wooden Cabinets. Cryst. Growth Des. 2015, 15, 2795-2800.

(16) Gibson, L. T.; Cooksey, B. G.; Littlejohn, D.; Linnow, K.; Steiger, M.; Tennent, N. H. The Mode of Formation of Thecotrichite, a Widespread Calcium Acetate Chloride Nitrate Efflorescence. Stud. Conserv. 2005, 50, 284-294.

(17) Apelblat, A.; Manzurola, E. Solubilities of magnesium, calcium, barium, cobalt, nickel, copper, and zinc acetates in water from $T=$ (278.15 to 348.15) K. J. Chem. Thermodyn. 1999, 31, 1347-1357.

(18) Klop, E. A.; Schouten, A.; van der Sluis, P.; Spek, A. L. Structure of calcium acetate monohydrate, $\mathrm{Ca}\left(\mathrm{C}_{2} \mathrm{H}_{3} \mathrm{O}_{2}\right)_{2} \cdot \mathrm{H}_{2} \mathrm{O}$. Acta Crystallogr., Sect. C: Cryst. Struct. Commun. 1984, 40, 51-53.

(19) van der Sluis, P.; Schouten, A.; Spek, A. L. Structure of a second polymorph of calcium acetate monohydrate. Acta Crystallogr., Sect. C: Cryst. Struct. Commun. 1987, 43, 1922-1924.

(20) Helems, R.; Cole, L. B.; Holt, E. M. Calcium complexes of mixed ligands: $\mathrm{Ca}_{2}(\text { acetate })_{4}(\mathrm{HOH})_{2}$ and $\mathrm{Ca}_{1.5}(\text { salicylate })_{2}$ (acetate)$(\mathrm{HOH})_{2}$ (acetic acid). Inorg. Chim. Acta 1988, 152, 9-15.

(21) Panzer, J. Nature of Calcium Acetate. J. Chem. Eng. Data 1962, 7, $140-142$.

(22) Walter-Levy, L.; Laniepce, J. Varieties of anhydrous calcium acetate. Compt. Rend. 1960, 250, 3320-2.

(23) Bette, S.; Stelzner, J.; Eggert, G.; Schleid, T.; Matveeva, G.; Kolb, U.; Dinnebier, R. E. Corrosion of heritage objects: collagen-like triple helix found in the calcium acetate hemihydrate crystal structure. Angew. Chem., Int. Ed. 2020, 59, 9438.

(24) Ashiotis, G.; Deschildre, A.; Nawaz, Z.; Wright, J. P.; Karkoulis, D.; Picca, F. E.; Kieffer, J. The fast azimuthal integration Python library: pyFAI. J. Appl. Crystallogr. 2015, 48, 510-519.

(25) Wright, C. J.; Zhou, X. D. Computer-assisted area detector masking. J. Synchrotron Radiat. 2017, 24, 506-508.

(26) Coelho, A. A. TOPAS and TOPAS-Academic: an optimization program integrating computer algebra and crystallographic objects written in C++. J. Appl. Crystallogr. 2018, 51, 210-218.

(27) Coelho, A. A. Indexing of powder diffraction patterns by iterative use of singular value decomposition. J. Appl. Crystallogr. 2003, 36, 8695.

(28) Le Bail, A.; Duroy, H.; Fourquet, J. L. Ab-initio structure determination of $\mathrm{LiSbWO}_{6}$ by X-ray powder diffraction. Mater. Res. Bull. 1988, 23, 447-452.

(29) Cheary, R. W.; Coelho, A. A.; Cline, J. P. Fundamental Parameters Line Profile Fitting in Laboratory Diffractometers. J. Res. Natl. Inst. Stand. Technol. 2004, 109, 1-25.

(30) Coelho, A. A. Whole-profile structure solution from powder diffraction data using simulated annealing. J. Appl. Crystallogr. 2000, 33, 899-908.

(31) Favre-Nicolin, V.; Černý, R. FOX: Modular Approach to Crystal Structure Determination from Powder Diffraction. Mater. Sci. Forum 2004, 443-444, 35-38.

(32) Rietveld, H. M. A profile refinement method for nuclear and magnetic structures. J. Appl. Crystallogr. 1969, 2, 65-71.
(33) Cliffe, M. J.; Goodwin, A. L. PASCal: a principal axis strain calculator for thermal expansion and compressibility determination. $J$. Appl. Crystallogr. 2012, 45, 1321-1329.

(34) Deacon, G. Relationships between the carbon-oxygen stretching frequencies of carboxylato complexes and the type of carboxylate coordination. Coord. Chem. Rev. 1980, 33, 227-250.

(35) Spinner, E. 812. The vibration spectra of some substituted acetate ions. J. Chem. Soc. 1964, 4217-4226.

(36) Baraldi, P.; Fabbri, G. Study of the bands attributable to crystallization water in hydrated metal acetates. Spectrochim. Acta, Part A 1981, 37, 89-92.

(37) Baraldi, P. Thermal behavior of metal carboxylates: III-metal acetates. Spectrochim. Acta, Part A 1982, 38, 51-55.

(38) Musumeci, A. W.; Frost, R. L.; Waclawik, E. R. A spectroscopic study of the mineral paceite (calcium acetate). Spectrochim. Acta, Part A 2007, 67, 649-61.

(39) Thommes, M.; Kaneko, K.; Neimark, A. V.; Olivier, J. P.; Rodriguez-Reinoso, F.; Rouquerol, J.; Sing, K. S. W. Physisorption of gases, with special reference to the evaluation of surface area and pore size distribution (IUPAC Technical Report). Pure Appl. Chem. 2015, $87,1051-1069$.

(40) Irish, D. E.; Semmler, J.; Taylor, N. J.; Toogood, G. E. Structure of magnesium diacetate tetrahydrate. Acta Crystallogr., Sect. C: Cryst. Struct. Commun. 1991, 47, 2322-2324.

(41) Bragg, W. H.; Morgan, G. T. Crystal structure and chemical constitution of basic beryllium acetate and propionate. Proc. R. Soc. London, Ser. A 1923, 104, 437-451.

(42) Koyama, H.; Saito, Y. The Crystal Structure of Zinc Oxyacetate, $\mathrm{Zn}_{4} \mathrm{O}\left(\mathrm{CH}_{3} \mathrm{COO}\right)_{6}$. Bull. Chem. Soc. Jpn. 1954, 27, 112-114.

(43) Hessel, L. W.; Romers, C. The crystal structure of "anhydrous" manganic acetate. Recueil des Travaux Chimiques des Pays-Bas 1969, 88, $545-552$.

(44) Poul, L.; Jouini, N.; Fiévet, F. Layered Hydroxide Metal Acetates (Metal = Zinc, Cobalt, and Nickel): Elaboration via Hydrolysis in Polyol Medium and Comparative Study. Chem. Mater. 2000, 12, 31233132.

(45) Bette, S.; Kremer, R. K.; Eggert, G.; Tang, C. C.; Dinnebier, R. E. On verdigris, part I: synthesis, crystal structure solution and characterisation of the $1-2-0$ phase $\left(\mathrm{Cu}_{3}\left(\mathrm{CH}_{3} \mathrm{COO}\right)_{2}(\mathrm{OH})_{4}\right)$. Dalton Trans. 2017, 46, 14847-14858.

(46) Bette, S.; Kremer, R.; Eggert, G.; Dinnebier, R. E. On Verdigris, Part II: Synthesis of the 2-1-5 Phase, $\mathrm{Cu}_{3}\left(\mathrm{CH}_{3} \mathrm{COO}\right)_{4}(\mathrm{OH})_{2} \cdot 5 \mathrm{H}_{2} \mathrm{O}$, by long-term crystallisation from aqueous solution at room temperature. Dalton Trans. 2018, 47, 8209-8220.

(47) Gautier-Luneau, I.; Mosset, A. Crystal structure of anhydrous barium acetate. J. Solid State Chem. 1988, 73, 473-479.

(48) Clegg, W.; Little, I. R.; Straughan, B. P. Monoclinic anhydrous zinc(II) acetate. Acta Crystallogr., Sect. C: Cryst. Struct. Commun. 1986, 42, 1701-1703.

(49) Weber, B.; Betz, R.; Bauer, W.; Schlamp, S. Crystal Structure of Iron(II) Acetate. Z. Anorg. Allg. Chem. 2011, 637, 102-107.

(50) Cotton, F. A.; Rice, C. E.; Rice, G. W. Crystal and molecular structure of anhydrous tetraacetatodichromium. J. Am. Chem. Soc. 1977, 99, 4704-4707.

(51) Bette, S.; Costes, A.; Kremer, R. K.; Eggert, G.; Tang, C. C.; Dinnebier, R. E. On Verdigris, Part III: Crystal Structure, Magnetic and Spectral Properties of Anhydrous Copper(II)-acetate, a Paddle Wheel Chain. Z. Anorg. Allg. Chem. 2019, 645, 988-997.

(52) Cotton, F. A.; Mester, Z. C.; Webb, T. R. Dimolybdenum tetraacetate. Acta Crystallogr., Sect. B: Struct. Crystallogr. Cryst. Chem. 1974, 30, 2768-2770.

(53) Cotton, F. A.; DeBoer, B. G.; LaPrade, M. D.; Pipal, J. R.; Ucko, D. A. The crystal and molecular structures of dichromium tetraacetate dihydrate and dirhodium tetraacetate dihydrate. Acta Crystallogr., Sect. B: Struct. Crystallogr. Cryst. Chem. 1971, 27, 1664-1671.

(54) Yadava, K.; Gallo, G.; Bette, S.; Mulijanto, C. E.; Karothu, D. P.; Park, I.-H.; Medishetty, R.; Naumov, P.; Dinnebier, R. E.; Vittal, J. J. Extraordinary anisotropic thermal expansion in photosalient crystals. IUCrJ 2020, 7, 83-89. 
(55) Chen, Z.; Gallo, G.; Sawant, V. A.; Zhang, T.; Zhu, M.; Liang, L.; Chanthapally, A.; Bolla, G.; Quah, H. S.; Liu, X.; Loh, K. P.; Dinnebier, R. E.; Xu, Q. H.; Vittal, J. J. Giant Enhancement of Second Harmonic Generation Accompanied by the Structural Transformation of 7-Fold to 8-Fold Interpenetrated Metal-Organic Frameworks (MOFs). Angew. Chem., Int. Ed. 2020, 59, 833-838.

(56) Zhou, H.-L.; Zhang, Y.-B.; Zhang, J.-P.; Chen, X.-M., Supramolecular-jack-like guest in ultramicroporous crystal for exceptional thermal expansion behaviour. Nat. Commun. 2015, 6. DOI: $10.1038 /$ ncomms7917

(57) Goodwin, A. L.; Calleja, M.; Conterio, M. J.; Dove, M. T.; Evans, J. S. O.; Keen, D. A.; Peters, L.; Tucker, M. G. Colossal Positive and Negative Thermal Expansion in the Framework Material $\mathrm{Ag}_{3}[\mathrm{Co}-$ $\left.(\mathrm{CN})_{6}\right]$. Science 2008, 319, 794-797. 